\title{
Immunoperoxidase localisation of human placental lactogen: a marker for the placental origin of the giant cells in 'syncytial endometritis' of pregnancy
}

\author{
EADIE HEYDERMAN,* AR GIBBONS,* AND SW ROSEN \\ From the *Department of Histopathology, St Thomas's Hospital Medical School, London SE1 7EH, and \\ †Clinical Endocrinology Branch NIAMDD, National Institutes of Health, Bethesda, MD, USA 20205
}

SUMMARY One hundred endometrial biopsies of various histological patterns, and material from 10 tubal pregnancies together with their associated uterine decidua, were examined for the presence of human placental lactogen using affinity-purified first and second antibodies and an indirect immunoperoxidase technique. Positive cells in endometrial curettings were seen only in association with an intrauterine pregnancy and morphologically resembled syncytiotrophoblast. Decidua associated with tubal pregnancy, pseudodecidua in progestogen-treated patients, and proliferative, secretory, and basal endometria were all negative. An immunoperoxidase stain for human placental lactogen is a useful marker for intrauterine pregnancy and supports the placental origin of the syncytial giant cells in so-called 'syncytial endometritis'. The technique is of potential value in those endometrial biopsies where pregnancy is suspected but no villi are seen.

The origin of the syncytial giant cells seen invading the maternal decidua in the placental site reaction, so-called 'syncytial endometritis', has long been subject for debate. They were considered originally by Ewing ${ }^{1}$ to represent a partly neoplastic, partly inflammatory process, and by Park $^{2}$ to be possibly of decidual or myoblastic derivation as well as of placental origin. Present opinion is that they are isolated syncytiotrophoblastic cells. ${ }^{3} 4$ As pointed out by Novak and Seah ${ }^{5}$ and Elston and Bagshawe, ${ }^{6}$ their appearance has been confused with that of choriocarcinoma but they are now recognised as a normal feature of human placentation.

It is common for pathologists to receive curettings from suspected pregnancy, missed abortion, or retained products of conception in which only decidua is present, containing a variable number of syncytial giant cells but no villi. If a specific pregnancy protein were localised only in morphologically identifiable fetal cells of placental origin and not in the non-pregnant endometrium, an immunoperoxidase stain for such a protein would be a useful marker of intrauterine pregnancy.

The object of this study was to investigate the presence of the placental hormone, human placental lactogen (HPL), in the endometrium and to see whether antisera to HPL would stain only syn- cytiotrophoblast-like cells (ie, fetal) or whether HPL can be localised in the normal endometrium. The cytotrophoblast is the generative element for syncytiotrophoblast ${ }^{7} 8$ and is prominent in the trophoblastic invasion of the placental bed. ${ }^{910} \mathrm{At}$ this time cytotrophoblastic cells can be identified only by morphological criteria. No well-characterised immunocytochemical markers are as yet available for their detection.

HPL is a single-chain polypeptide of molecular weight 22300 daltons. Isolated by Josimovitch and MacLaren in 1962,11 it has also been known as chorionic growth hormone-prolactin (CGP) and human chorionic somatomammotropin (HCS) because of its growth hormone-like and lactogenic properties. Indeed, the primary structure of HPL shows substantial sequence homology with those of human growth hormone and human prolactin. ${ }^{12}$ Placental lactogen is readily demonstrable in the syncytiotrophoblast, but not the cytotrophoblast, of the normal placenta by immunofluorescence ${ }^{13}$ and immunoperoxidase techniques. ${ }^{14}$

Human chorionic gonadotrophin (HCG), a glycoprotein composed of two different noncovalently linked subunits, alpha and beta it is also found in the syncytiotrophoblast of the normal placenta $^{15}$ and has been demonstrated in the giant 
cells of exuberant trophoblastic proliferation ('trophoblastic pseudotumour'). ${ }^{16}$ Since the $\alpha$ subunits of luteinising hormone, follicle-stimulating hormone, thyroid-stimulating hormone, and HCG are at present immunologically indistinguishable, ${ }^{17}$ the localisation of HCG requires antisera directed against the hormone-specific $\beta$ subunit. ${ }^{18}$ However, HPL is easier to demonstrate in the normal placenta than is HCG- $\beta^{19}$ so that if one uses antisera to HCG- $\beta$, much higher concentrations and therefore uneconomic quantities of antiserum are required. Antisera to HPL are readily available, and HPL for absorption and/or affinity purification is obtainable in milligram amounts; this is unfortunately not yet true for HCG- $\beta$. Antisera to pregnancy-specific beta glycoprotein $\left(\mathrm{SP}_{1}\right)^{20} 21$ were not used since available antisera stain some normal secretory epithelia (unpublished data).

\section{Methods and tissues}

Sections 3-4 $\mu$ thick were cut from blocks of formalin-fixed, paraffin-embedded, routine endometrial curettings and surgical material from tubal pregnancies. These were stained for HPL using an indirect immunoperoxidase technique which includes inhibition of endogenous peroxidase. ${ }^{22}$ Blood clot, haemorrhage, or inflammatory cells are frequently present, and unless endogenous peroxidase activity is blocked, interpretation may be very difficult due to false localisation of staining in such areas. ${ }^{23}$

\section{ANTISERA AND CONTROLS}

HPL was supplied by the Hormone Distribution Program of the National Institute of Child Health and Human Development. HPL was covalently linked to cyanogen bromide-activated agarose (Sepharose 4B, Pharmacia Fine Chemicals, Piscataway, NJ, USA) by the method described in the manufacturer's brochure. Antisera to HPL, raised in rabbits, were passed through a column containing staphylococcal protein A covalently linked to agarose (Protein A-Sepharose CL-4B, Pharmacia). These antisera gave no significant cross reaction with human prolactin in radioimmunoassay experiments (unpublished data). The IgG fraction was eluted from the column with $0 \cdot 1 \mathrm{~N}$ acetic acid, dialysed against phosphate-buffered saline containing $0.02 \%(w / v)$ sodium azide, and passed down the column of Sepharose-HPL. The anti-HPL IgG was eluted in a solution of $6 \mathrm{M}$ guanidine hydrochloride, pH $3^{24}$ and dialysed immediately. It was used for immunostaining diluted $1: 15$. This affinity purified reagent was again passed down the Sepharose-HPL column and the effluent was used as an 'absorbednegative control. The $6 \mathrm{M}$ guanidine eluate from this passage produced specific though weak staining.

The second antibody, affinity-purified sheep anti-rabbit immunoglobulin, was kindly supplied by Dr O'Sullivan (Guildhay) and conjugated according to the method of Nakane and Kawaio. ${ }^{25}$

\section{Results}

The syncytiotrophoblast of the first-trimester placenta was always positive with anti HPL (Fig. 1) and unstained by the negative control serum. An identical reaction was seen in syncytial giant cells and in the trophoblastic covering of the villi in the endometrial curettings.

Endometria showing progestogen-therapy-induced pseudodecidual change, proliferative, secretory, or basal pattern were all negative, as were uterine decidua from patients with tubal pregnancies (Fig. 2; Table).The latter showed positive but of ten rather poor staining of the tubal chorionic villi (see discussion).

Indirect immunoperoxidase stain for human placental lactogen in endometrial biopsies and ectopic tubal implantation sites

\begin{tabular}{|c|c|c|}
\hline & $\begin{array}{l}\text { Number of } \\
\text { cases }\end{array}$ & $\begin{array}{l}\text { Number } \\
\text { positive }\end{array}$ \\
\hline 'Syncytial endometritis' & 25 & 25 \\
\hline Tubal implantation sites & 10 & 10 \\
\hline \multicolumn{3}{|l|}{ Decidual reactions } \\
\hline 'Pseudodecidua' & & \\
\hline (progestogen therapy) & 15 & Nil \\
\hline $\begin{array}{l}\text { Decidua (intrauterine } \\
\text { pregnancy) }\end{array}$ & 7 & $\mathrm{Nil}$ \\
\hline $\begin{array}{l}\text { Uterine decidua (tubal } \\
\text { pregnancy) }\end{array}$ & 10 & Nil \\
\hline \multicolumn{3}{|l|}{ Endometrial curettings } \\
\hline Proliferative & 23 & $\mathrm{Nil}$ \\
\hline Secretory & 18 & Nil \\
\hline Late secretory/menstrual & $\bar{y}$ & Nil \\
\hline Basal/inactive & 3 & Nil \\
\hline
\end{tabular}

All the endometrial biopsies of 'syncytial endometritis' alone or 'syncytial endometritis' with villi elsewhere showed positive but patchy staining of syncytial giant cells (Figs 3-5) and villi. Some syncytiotrophoblastic cells were negative while morphologically similar cells were positive. A patchy distribution of staining was also seen in the normal placenta and has been noted in the localisation of placental hormones in testicular tumours ${ }^{19}$ and in extragonadal tumours associated ${ }^{24}$ with ectopic HPL production (unpublished data). Positive cells were less frequent when the curettings were from a missed abortion or retained products with necrotic and/or acutely inflamed decidua and were not seen in frankly necrotic areas. Some decidua contained syncytiotrophoblastic cells not detected in the $H$ and $E$ preparation, and often there were more positive cells than was suspected. Many cells were mononuclear and mainly distinguished in the $\mathrm{H}$ and $\mathrm{E}$ by their eosinophilia. Decidua without 

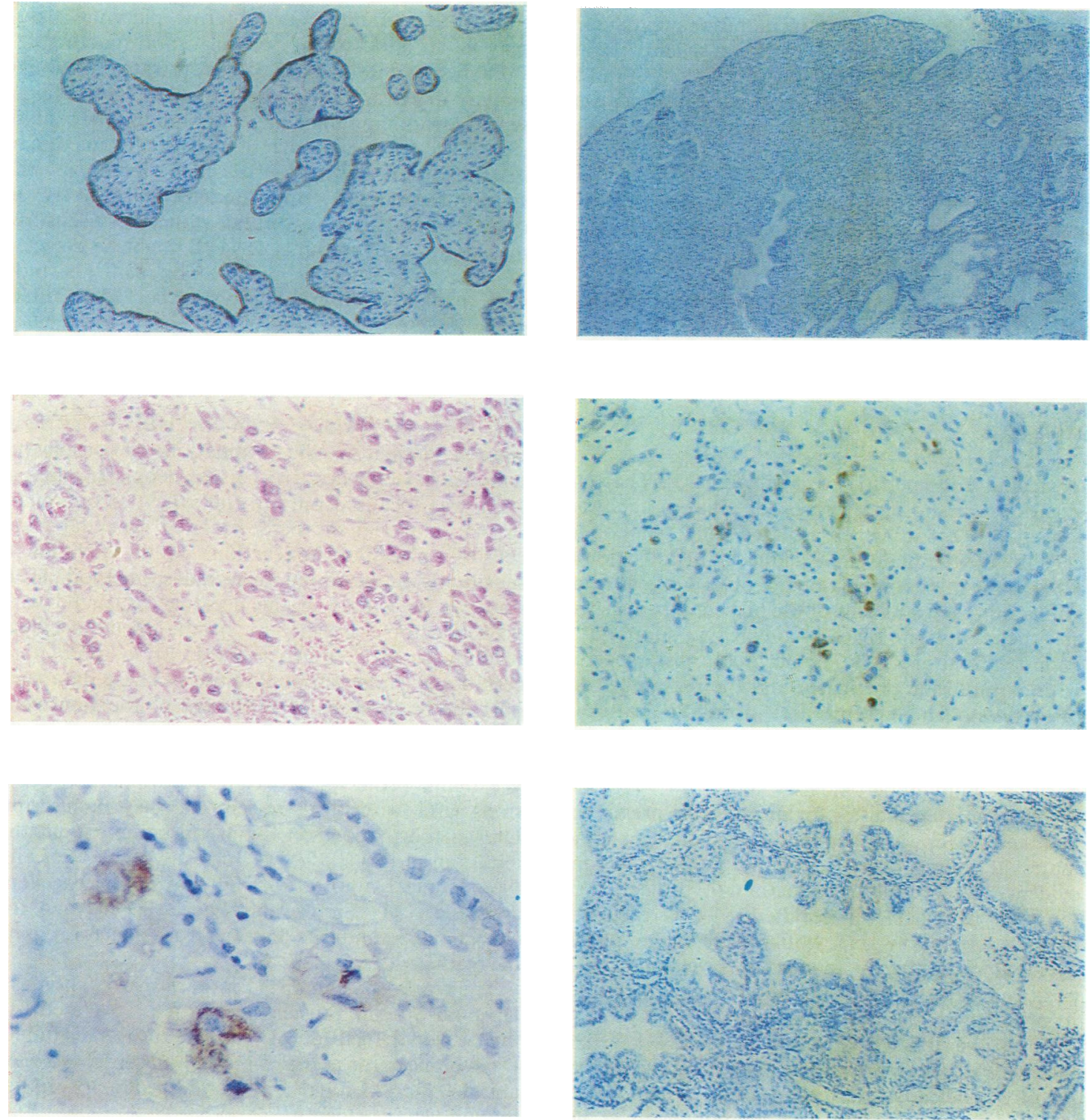

Figs 1, 2, 4, 5, and 6 Indirect immunoperoxidase stain using affinity-purified antisera to human placental lactogen.

Fig. 1 First trimester placenta stained with affinity-purified antiserum to HPL. The syncytiotrophoblast is strongly positive, although the distribution of staining is patchy. The cytotrophoblast and stroma of the chorionic villi are negative. $\times 45$.

Fig. 2 Uterine decidua from patient with ectopic tubal pregnancy. Immunostain for HPL is negative. $\times 20$.

Fig. 3 'Syncytial endometritis'. $H$ and E preparation shows trophoblastic cells, many of which are mononuclear, invading the uterine decidua. A similar reaction may be seen in a tubal implantation site. $\times 70$.

Fig. 4 Syncytiotrophoblastic cells seen in Fig. 3 are positively stained for HPL. Once again a patchy distribution of staining is seen. $\times 70$.

Fig. 5 At higher power the syncytiotrophoblastic cells from another example of 'syncytial endometritis' show their bizarre shape and characteristic vesicular cytoplasmic pattern of staining. $\times 180$.

Fig. 6 Arias-Stella reaction of pregnancy is negative for HPL. $\times 70$. 
giant cells, but from known intrauterine pregnancies, were not positively stained, so that a negative result did not exclude pregnancy (Fig. 6).

All but two of the HPL-positive endometria were from patients with clinically proven intrauterine pregnancy. Some were from terminations of pregnancy, some from missed abortions, and others were retained products after vaginal delivery of a live infant. One patient, in whom pregnancy could not be confirmed clinically, had irregular periods, was curetted during an operation for sterilisation, and found to have decidua containing HPL-positive syncytial giant cells. In another patient, a pregnancy test after curettage was negative, and pregnancy was therefore not confirmed.

\section{Discussion}

'Syncytial endometritis' is a misnomer. ${ }^{26}$ The term suggests a pathological basis for what is a physiological process in which isolated fetal trophoblast cells invade the maternal decidua. ${ }^{3}{ }^{9}$ Localisation of HPL only in the syncytiotrophoblast of chorionic villi and in the giant cells of the placental bed, as well as their morphological similarity, supports a common fetal origin. ${ }^{26}$ The decidual cells associated with extrauterine pregnancy and the pseudodecidua of progestogen therapy are morphologically indistinguishable from those of intrauterine pregnancy and show no evidence of HPL localisation. A positive immunoperoxidase stain for HPL is therefore a good marker for intrauterine pregnancy. Our results do not support a decidual or other maternal source of HPL, ${ }^{2}$ although there is some evidence for decidual production of prolactin, the pituitary lactogen. ${ }^{27}$ If decidual cells were capable of HPL secretion one would expect the uterine decidual response to an ectopic pregnancy to be positive, and it is not. The pseudodecidual reaction to progestogen therapy is also negative.

Assertions that HPL cannot be localised in fixed material $^{28}$ have previously been refuted. ${ }^{14}$ 29-31 Affinity-purified antiserum to HPL, which retains its binding capacity in radioimmunoassay, ${ }^{24}$ was used and produced discrete convincing localisation; an absorption control resulted in abolition of positive staining. Localisation in the syncytiotrophoblast is consistent with the ultrastructural distribution of rough endoplasmic reticulum of the placenta. ${ }^{32}$

The poor staining of syncytiotrophoblastic cells in necrotic or inflamed decidua and in some tubal pregnancies is noteworthy. It seems that, unlike HCG- $\beta,{ }^{19}$ HPL activity disappears rapidly after death of the cell. In view of the data showing low circulating HPL levels in high-risk pregnancies, ${ }^{33}$ the weak staining of extrauterine placental tissue may be an indicator of poor placental function.

Payne and Ryan ${ }^{34}$ have demonstrated HPL-like activity in extracts of the normal adult testis using a sensitive radioimmunoassay. Our immunoperoxidase assay has been designed to obtain the maximum discrimination between the high levels in the syncytiotrophoblast and undetectable levels in other tissues. It is possible that, with a more sensitive method, minute amounts of HPL might be detected in other normal tissues, but the object of this study was maximum discrimination rather than ultrasensitive detection.

\section{Conclusion}

An immunoperoxidase stain for HPL is a useful 'special stain' in the evaluation of suspicious endometrial biopsies. In the non-neoplastic uterus, HPL was localised only in the syncytiotrophoblast of placental villi or in the isolated syncytial giant cells of a placental site reaction. Within the limits of sensitivity of the immunoperoxidase method, HPL was not detectable in the decidua associated with proven ectopic pregnancy, in the pseudodecidual reaction to progestogen therapy, or in other nongestational endometrial curettings. These data support the fetal origin of HPL and of the giant cells of 'syncytial endometritis'.

We thank Professor JR Tighe for valuable discussions and a critical review of the manuscript, Dr Malcolm Anderson for useful comments at the initiation of this study, Ms Ida Calvert at NIH and the technical staff at St Thomas's for excellent assistance, Ms Emma and Laura Heyderman for clerical help, and Ms Patricia Robbins for typing the manuscript.

The work was supported in part by St Thomas's Hospital Special Trustees Fund. We are grateful to the National Institute of Child Health and Human Development for a gift of human placental lactogen and to the National Pituitary Agency for radioimmunoassay reagents.

\section{References}

${ }^{1}$ Ewing J. Chorioma: a clinical and pathological study. Surg Gynec Obstet 1910;10:366-92.

${ }^{2}$ Park WW. Choriocarcinoma. A study of its pathology. London: William Heinemann, 1971;22.

${ }^{3}$ Boyd JD, Hamilton WJ. The giant cells of the pregnant human uterus. J Obstet Gynaec Br Emp 1960;67:208-17.

${ }^{4}$ Robertson WB, Warner B. Ultrastructure of the human placental bed. J Path 1974;112:203-11.

${ }^{5}$ Novak E, Seah CS. Benign trophoblastic lesions in Mathieu chorionepithelioma registry (hydatidiform mole, syncytial endometri is). Amer J Obstet Gynaec 1954; 
$68: 376-90$.

- Elston CW, Bagshawe KD. The diagnosis of trophoblastic tumours from uterine curettings. J Clin Pathol 1972;25: 111-8.

7 Tighe JR, Garrod PR, Curran RC. The trophoblast of the human chorionic villus. J Path Bact 1967;93:559-67.

${ }^{8}$ Okudaira Y, Susuki S, Okudaira M, Hashimoto T, Hayakawa K. Electron microscopic observations on the formation of syncytiotrophoblast from cytotrophoblast. J Electron Microsc 1968;17:47-54. (Japanese text, English summary.)

9 Pijnenborg R, Dixon G, Robertson WB, Brosens I. Trophoblastic invasion of human decidua from 8 to 18 weeks of pregnancy. Placenta 1980;1:3-19.

10 De Wolf F, De Wolf-Peeters C, Brosens I. Ultrastructure of the spiral arteries in the human placental bed at the end of normal pregnancy. Am J Obstet Gynaec 1973;111: 833-48.

11 Josimovich JB, MacLaren JA. Presence in the human placenta and term serum of a highly lactogenic substance immunologically related to pituitary growth hormone. Endocrinology 1962;71:209-20.

12 Niall HD, Hogan ML, Tregear GW, Segre GV, Hwang P, Friesen H. The chemistry of growth hormone and the lactogenic hormones Rec Prog Horm Res 1973;29: 387-416.

${ }^{13}$ Currie AR, Beck JS, Ellis ST, Read CH. Immunofluorescent localisation of a growth hormone-like factor in normal and abnormal syncytiotrophoblast. $J$ Path Bact $1966 ; 92: 395-9$.

${ }^{14}$ Heyderman E, Neville AM. Immunoperoxidase technique in routine histopathology. Lancet $1978 ; \mathbf{i i}: 1382$.

${ }^{15}$ Heyderman E, Neville AM. Syncytiotrophoblasts in malignant testicular tumours. Lancet 1976;ii:103.

16 Kurman RJ, Scully RE, Norris HJ. Trophoblastic pseudotumor of the uterus. An exaggerated form of 'syncytial endometritis' simulating a malignant tumor. Cancer 1976;38:1214-26.

17 Morgan FJ, Canfield RE. Nature of the subunits of human chorionic gonadotrophin. Endocrinology 1971;88: 1045-53.

18 Vaitukaitis JL, Braunstein GD, Ross GT. A radioimmunoassay which specifically measures human chorionic gonadotropin in the presence of human luteinizing hormone. Am J Obstet Gynec 1972;113:751-8.

19 Heyderman E. Multiple tissue markers in human malignant testicular tumours. Carcinoembryonic Proteins: Recent Progress. Scand J Immunol 1978;Suppl 8:119-26.

${ }^{20}$ Bohn H. Nachweis und Charakterisierung von Schwanger- schaftsproteinen in der menschlichen Placenta, sowie ihre quantitätive immunologische Bestimmung im Serum schwangeren Frauen. Arch Gynäk 1971 ;210: 440-57.

${ }^{21}$ Horne CHW, Towler CM, Milne GD. Detection of pregnancy specific $\beta_{1}$-glycoprotein in formalin-fixed tissues. J Clin Pathol 1977;30:19-33.

${ }^{22}$ Heyderman E. Immunoperoxidase technique in histopathology: applications, methods, and controls. $J$ Clin Pathol 1979;32:971-8.

${ }^{23}$ Heyderman E, Neville AM. A shorter immunoperoxidase technique for the demonstration of carcinoembryonic antigen and other cell products. J Clin Pathol 1977; 30:138-40.

${ }^{24}$ Weintraub BD, Rosen SW. Ectopic production of human chorionic somatomammotropin by non trophoblastic cancers. J Clin End \& Metab 1971;32:94-101.

${ }^{25}$ Nakane PK, Kawaio A. Peroxidase-labeled antibody: a new method of conjugation.J Histochem Cytochem 1974; 22:1084-91.

${ }^{26}$ Boyd JD, Hamilton WJ. The human placenta. Cambridge: Heffer, 1970:182-3

${ }^{27}$ Riddick DH, Kusmik WF. Decidua: a possible source of amniotic fluid prolactin. Am J Obstet Gynec 1977;127: $187-90$.

${ }^{28} \mathrm{Gau} \mathrm{G}$, Chard T. Location of the protein hormones of the placenta by the immunoperoxidase technique. Br J Obstet Gynaec 1976;83:896-8.

29 Horne CHW, Reid IN, Milne GD. Prognostic significance of inappropriate production of pregnancy proteins by breast cancers. Lancet 1976;ii:279-82.

${ }^{30}$ Watkins WB. Use of immunocytochemical techniques for the localisation of human placental lactogen. $J$ Histochem Cytochem 1978;26:288-92.

${ }^{31}$ Heyderman E, Monaghan P. Immunoperoxidase reactions in resin-embedded sections. Invest Cell Pathol 1979;2: 119-22.

${ }^{32}$ Wislocki GB, Dempsey EW. Electron microscopy of the human placenta. Anat Rec 1955;123/2:133-67.

${ }^{33}$ Teoh ES, Spellacy WN, Buhi WC. Human chorionic somatomammotrophin (HCS): a new index of placental function. J Obstet Gynaec Br Cmwlth 1971:78/8:673-85.

${ }^{34}$ Payne RA, Ryan RJ. Human placental lactogen in the male subject. J Urol 1972;107:99-103.

Requests for reprints to: Dr E Heyderman, Department of Histopathology, St Thomas's Hospital Medical School, London SE1 7EH. 